\title{
Identification of exotic North American crayfish in Europe by DNA barcoding
}

\author{
L. Filipová(1,2), F. Grandjean(2), C. Chucholl(3), D.M. Soes ${ }^{(4,5)}$, A. Petrusek ${ }^{(1)}$ \\ Received January 19, 2011 \\ Revised March 15, 2011 \\ Accepted March 16, 2011
}

Key-words: $\quad$ Several alien crayfish of North American origin have become established $\mathrm{COl}$ barcoding, invasive crayfish, Europe, North America, Orconectes, Procambarus

\section{ABSTRACT} in Europe in recent decades, but their identification is often confusing. Our aim was to verify the taxonomic status of their European populations by DNA barcoding. We sequenced the cytochrome $c$ oxidase subunit I (COI) gene fragment of individuals representing all American crayfish known from European waters, and compared the results with reference sequences from North America. Our results confirm the morphological identification of Orconectes juvenilis from a population in eastern France, and of the marbled crayfish (Marmorkrebs), i.e., a parthenogenetic form of Procambarus fallax, from south-western Germany. Sequences of most individuals of presumed Procambarus acutus from the Netherlands were similar to American $P$. cf. acutus, but one was divergent, closer to a sequence of a reference individual of $P$. cf. zonangulus. However, divergences among three American $P$. cf. zonangulus samples were also high, comparable to interspecific variation within cambarid species complexes. The divergence between $\mathrm{O}$. immunis from Europe and America also reached values corresponding to those observed among distinct Orconectes species. Genetic variation in the American range of these crayfish should therefore be further studied. Our study shows that DNA barcoding is useful for the rapid and accurate identification of exotic crayfish in Europe, and also provides insights into overall variation within these taxa.

\section{RÉSUMÉ}

Identification des écrevisses d'Amérique du Nord introduites en Europe par une méthode de DNA barcoding (code-barre génétique)

\author{
Mots-clés : \\ $\mathrm{COI}$ \\ code-barre \\ génétique,
}

\begin{abstract}
Plusieurs écrevisses provenant d'Amérique du Nord se sont établies en Europe pendant ces dernières dizaines d'années, mais leur identification est encore souvent confuse. Notre but était de vérifier le statut taxonomique de leurs populations en Europe en utilisant une méthode de DNA barcoding (code-barre génétique).
\end{abstract}

(1) Department of Ecology, Faculty of Science, Charles University in Prague, Viničná 7, 12844 Prague 2, Czech Republic, nely@seznam.cz

(2) Laboratoire Écologie, Évolution, Symbiose, UMR CNRS 6556, Université de Poitiers, 40 av. du Recteur Pineau, 86022 Poitiers Cedex, France

(3) Institute of Experimental Ecology (Bio III), University of Ulm, Albert Einstein Allee 11, 89069 Ulm, Germany

(4) Bureau Waardenburg, Postbus 365, 4100 AJ Culemborg, the Netherlands

(5) NCB Naturalis, Postbus 9517, 2300 RA Leiden, the Netherlands 
écrevisses

invasives,

Europe,

Amérique

du Nord,

Orconectes,

Procambarus
Nous avons séquencé le gène codant pour la sous-unité I de la cytochrome $c$ oxydase (COI) chez des individus qui représentent l'ensemble des écrevisses américaines rencontrées dans les eaux européennes. Ces données ont été ensuite comparées avec les séquences de référence d'individus d'Amérique du Nord. Nos résultats confirment l'identification morphologique d'Orconectes juvenilis provenant d'une population de l'est de la France et des écrevisses marbrées (Marmorkrebs), correspondant à la forme parthénogénétique de Procambarus fallax, du sud-ouest de l'Allemagne. Les séquences de la plupart des individus des Pays-Bas supposés appartenir à Procambarus acutus sont similaires à $P$. cf. acutus d'Amérique. Cependant, une séquence s'est révélée différente des autres, étant plus proche de séquence d'un individu de référence de $P$. cf. zonangulus. Néanmoins, les divergences parmi trois échantillons américains de $P$. cf. zonangulus sont aussi élevées et comparables à la variation interspécifique au sein des complexes d'espèces des Cambaridae. Les divergences entre O. immunis d'Europe et d'Amérique ont également atteint des valeurs similaires à celles qui ont été observées parmi des espèces d'Orconectes distinctes. La variation génétique dans l'aire de répartition de ces écrevisses en Amérique du Nord devrait donc être étudiée en détail. Ainsi, notre étude montre que la méthode de DNA barcoding est utile pour l'identification rapide et précise des écrevisses introduites en Europe. Elle peut également apporter de plus amples connaissances sur la variation totale dans ces taxa.

\section{INTRODUCTION}

About 120 years ago, the first crayfish originating from a different continent, the North American spiny-cheek crayfish Orconectes limosus (Rafinesque, 1817), became successfully established in Europe (Kossakowski, 1966). This was later followed during the 20th century by intentional introductions of several other exotic crayfish species (Gherardi and Holdich, 1999). Three of these became very widespread: the firstly introduced $O$. limosus, plus the signal crayfish Pacifastacus leniusculus (Dana, 1852) and the red swamp crayfish Procambarus clarkii (Girard, 1852). Given the importance of these invasive species for colonized aquatic ecosystems and for conservation of native crayfish species, their ecology, distribution, and impact have been studied intensively in recent decades (Gherardi and Holdich, 1999; Souty-Grosset et al., 2006). The genetic variation of European populations of these invaders has also received some attention (Grandjean and Souty-Grosset, 1997; Barbaresi et al., 2007; Filipová et al., 2009; Hulák et al., 2010). Recently, established populations of several other North American crayfish have been discovered in European waters. Most of these species, introduced to the wild after the mid-1990s, are likely to have come from the aquarium trade and, in contrast to well-established non-indigenous crayfish species ("Old NICS"), they are sometimes referred to as "New NICS" (Holdich et al., 2009).

The oldest "New NICS" of North American origin in Europe, the calico crayfish Orconectes immunis (Hagen, 1870), was first recorded in the mid-1990s in southern Germany (Dussling and Hoffmann, 1998; Gelmar et al., 2006). At present, it colonizes a stretch of approximately $100 \mathrm{~km}$ of the Upper Rhine plain in south-western Germany and eastern France (Holdich, 2003; Chucholl, 2006; Chucholl et al., 2008; M. Collas, pers. comm.). Its taxonomical status has never been questioned; however, the identification of other recently established American invaders has not been so straightforward.

A crayfish population found in 2004 in London, Great Britain, was first considered to be Orconectes limosus, but subsequent morphological examination of local individuals resulted in re-identification as the virile crayfish Orconectes virilis (Hagen, 1870) (Ahern et al., 2008). Similarly, O. virilis was known to be established in the Netherlands at least since 2004 (Soes and van Eekelen, 2006). Genetic analysis of individuals from both these European populations nevertheless revealed that they represent a new lineage of the $O$. virilis species complex; its original distribution in North America is not yet known (Filipová et al., 2010). 
In 2005, a population of another Orconectes species was found in the watershed of the river Doubs in eastern France (Daudey, 2006; Chucholl and Daudey, 2008). These crayfish were first identified as the highly invasive rusty crayfish Orconectes rusticus (Girard, 1852) (Daudey, 2006), and this identification continued to be used by authors of influential reference publications (Pöckl et al., 2006; Souty-Grosset et al., 2006). However, Chucholl and Daudey (2008) subsequently examined the morphology of these individuals in detail and identified them as Orconectes juvenilis (Hagen, 1870), as was also confirmed by Christopher A. Taylor (Illinois Natural History Survey). This species is relatively closely related to but distinct from $O$. rusticus (Taylor, 2000).

The identification of recently established species of the genus Procambarus in Europe is no less problematic. A good example is the complicated taxonomic history of the marbled crayfish ("Marmorkrebs"). This unusual lineage, the only known obligately parthenogenetic crayfish, started to spread in the German and Austrian aquarium trade in the mid-1990s (Scholtz et al., 2003; Souty-Grosset et al., 2006). It has received substantial research attention since the early 2000s (Scholtz et al., 2003) but was only recently unambiguously confirmed to be an asexual form of Procambarus fallax (Hagen, 1870) by both morphological and molecular approaches (Martin et al., 2010a). Marbled crayfish have been found in the wild in the Netherlands, Germany and Italy (Soes and van Eekelen, 2006; Souty-Grosset et al., 2006; Marzano et al., 2009; Chucholl and Pfeiffer, 2010; Martin et al., 2010b), although it seems that a well-established reproducing population has so far only been confirmed from south-western Germany (Chucholl and Pfeiffer, 2010).

Since at least 2005, another Procambarus species has been spreading in the Netherlands (Soes and van Eekelen, 2006). Its identity has not yet been unambiguously confirmed; it is considered to probably be $P$. acutus (Girard, 1852), but identification as $P$. zonangulus Hobbs and Hobbs, 1990 has also been discussed (Holdich et al., 2009). The presence of $P$. zonangulus in the wild in Germany was suggested by several authors (Dehus et al., 1999; Westman, 2002), but this was not later confirmed (Holdich, 2003). The taxonomy of these species, both generally referred to as white river crayfish, is not clear even in North America; with at least one closely related species being still undescribed (Huner et al., 1994; Fetzner et al., 1997).

The history of most "New NICS" of North American origin given above clearly shows that identification of such invaders is not a simple task. To obtain reliable conclusions, one should not rely exclusively on a single approach (e.g., morphological examination of a few individuals) but more complex analyses are recommended. Classical approaches may be well combined with the analysis of species-specific molecular markers, which now allows relatively simple testing of taxonomic hypotheses. DNA barcoding, i.e., the use of standardized DNA sequences for species identification, was proposed in the early-2000s as a particularly promising tool (Hebert et al., 2003). Although any single molecular marker should be used with care, especially as some publicly available reference data may be flawed (Buhay, 2009) or from misidentified specimens, mitochondrial DNA sequences have turned out to be a suitable method for crayfish identification. In addition to the above-mentioned cases (Filipová et al., 2010; Martin et al., 2010a), this approach has been successfully used, for example, to confirm the identity of marbled crayfish found in Italy (Marzano et al., 2009) and Germany (Martin et al., 2010b), or of Cherax destructor (Clark, 1936) recently established in Italy (Scalici et al., 2009).

The traditional barcoding marker suggested for most animal phyla (Hebert et al., 2003) is a fragment of the mitochondrial gene for subunit I of the cytochrome $c$ oxidase (COI). This marker has been used in several phylogenetic studies on North American crayfish (e.g., Taylor and Hardman, 2002; Taylor and Knouft, 2006; Mathews et al., 2008; Dillman et al., 2010), so it is available for a number of potential invaders (although care must be taken when interpreting some data; see Buhay, 2009). The aim of our study is to assemble reference COI sequence data for the North American crayfish known to be present in Europe, to confirm the identification of those species that have not been analysed genetically, and to highlight the potential as well as limitations of DNA barcoding when identifying crayfish invaders. 


\section{MATERIAL AND METHODS}

We collected publicly available COI sequences from previous studies that analyzed the mitochondrial COI marker in European populations of North American invasive crayfish species (references and GenBank accession numbers are given in Table I). Additionally, we obtained individuals of exotic crayfish populations not yet analyzed genetically: one individual of presumed Orconectes juvenilis from the river Dessoubre in France (provided by M. Bramard), two individuals of presumed $\mathrm{O}$. immunis from Au am Rhein in Germany and eight individuals from Reiperstwiller in France (collected by C. Chucholl and M. Collas, respectively), and 10 individuals of presumed Procambarus acutus from Neder-Hardinxveld in the Netherlands (coll. by D.M. Soes). Individuals from an established marbled crayfish population were captured in the lake Moosweiher in south-western Germany (coll. by C. Chucholl). We also included representative samples of "Old NICS" from Europe in the analysis: Orconectes limosus, Pacifastacus leniusculus and Procambarus clarkii. A summary of all sampled localities is given in Table I.

Reference $\mathrm{COI}$ sequences from North American populations of the respective species were mostly obtained from public sources or our unpublished results (Table I). When available, distinct COI haplotypes from North America were chosen to approximately represent the extent of variation of the respective taxon in the native range. Based on the results of Taylor and Knouft (2006), we added sequences of species closely related to "New NICS" to our analysis; only lineages diverging by less than an arbitrarily chosen threshold of $4 \%$ were included. When several GenBank sequences of reference species were identical, only one of them was used in the tree. A sequence of $O$. rusticus was also included due to the confusion of European $O$. juvenilis with this species in the past. Additionally, we added a sequence of $O$. quinebaugensis Mathews and Warren, 2008 to complete the O. virilis species complex (see Filipová et al., 2010 for details), although its divergence from European O. cf. virilis slightly exceeded the chosen threshold.

For comparative purposes, we also used sequences of O. cristavarius Taylor, 2000 and O. immunis from Taylor and Knouft (2006), although these were shown by Buhay (2009) to contain extra insertions close to the 5 ' end (one or two nucleotides, respectively), and were therefore flagged as "COI-like" sequences in GenBank. Given the position of these problematic regions close to the end of the sequence (and outside of the fragment used in our analysis), and the fact that the amino-acid translation of the preceding sequence does not contain stop codons and agrees with that of other closely related species, we consider these likely to be errors in manual editing and/or a lack of quality control (as suggested by Buhay, 2009) rather that pseudogene sequences. However, careful interpretation of these particular sequences is necessary; therefore these are marked in the tree.

DNA extraction and sequencing of the $\mathrm{COI}$ gene fragment followed the methods described in Filipová et al. (2010). The DNA was extracted from crayfish leg muscle tissue following a Chelex extraction protocol with proteinase $\mathrm{K}$. The analyzed COI fragment was amplified with the universal primers HCO2198 and LCO1490 (Folmer et al., 1994). Purified PCR products were sequenced in both directions on a capillary sequencer (ABI PRISM 3130), using a BigDye v. 3.1 Terminator Kit. After removal of primer sequences, this resulted in a $658 \mathrm{bp}$ long partial $\mathrm{COI}$ sequence. All analyzed sequences were aligned and analyzed in the software MEGA 4.0 (Tamura et al., 2007). The same program was used to construct a neighbour-joining tree and to calculate divergences, using the Kimura 2-parameter model and pairwise deletion of missing data. We provide the neighbour-joining tree (with branch support calculated from 1000 bootstrap pseudoreplications) to show the pattern of COI similarity, as the barcoding approach is based on sequence comparison, not phylogenetic analyses. Furthermore, we assessed the relationship of the taxa included in our analysis by Bayesian inference of phylogeny in MrBayes v. 3.1.2 (Ronquist and Huelsenbeck, 2003). Independent analyses were performed with settings corresponding to two best-fitting models of evolution, $G T R+I+G$ and $\mathrm{HKY}+\mathrm{I}+\mathrm{G}$, which were suggested in MrModeltest 2.3 (Nylander, 2004); each analysis consisted of two parallel runs of four Monte Carlo Markov chains run for 3 million generations ( $20 \%$ of which were disregarded as a burn-in phase), with trees sampled every 100 generations. Both models resulted in identical tree topology and almost identical branch support 
in Bayesian inference, therefore only results of the latter are provided. Newly obtained sequences were submitted to Genbank (accession numbers JF437985-JF438007).

\section{RESULTS}

The patterns of similarity for the COI sequences from European populations of invasive North American crayfish and their American counterparts and relatives are shown in the neighbourjoining tree in Figure 1. The barcoding approach should not be considered a phylogenetic hypothesis; however, the general tree topology agreed well with the results of the Bayesian inference (branch support values are given in Figure 1), and the three genera and main clades within them were recovered by both methods.

As expected, identification of all three "Old NICS", O. limosus, P. leniusculus, and P. clarkii, is completely clear. The maximum intraspecific variation among individuals of European origin included in our study was $0.15 \%$ in 0 . limosus, $0.6 \%$ in P. clarkii and $2.32 \%$ in P. leniusculus. Pacifastacus leniusculus from Europe were relatively variable, all of them were nevertheless more similar to a reference sequence representing the nominate subspecies $P$. I. leniusculus (Dana, 1852) (average divergence 1.13\%, maximum 2.48\%) than to individuals of the other two recognized subspecies P. I. trowbridgii (Stimpson, 1857) and P. I. klamathensis (Stimpson, 1857) (average divergences $4.67 \%$ and $5.01 \%$, respectively).

The sequenced marbled crayfish individuals from south-western Germany agreed with the morphological identification; they were identical to previously sequenced marbled crayfish, and similar to reference sequences of $P$. fallax from Florida (divergence $0.61 \%$ to both US sequences). Similarly, the tested individual from the Dessoubre in eastern France was confirmed to be $O$. juvenilis. It differed by $0.46 \%$ from the reference sequence of $O$. juvenilis from Kentucky, USA. The pairwise divergence between the French specimen and O. rusticus was $4.42 \%$; divergences to other analysed closely related species, O. cristavarius, O. jeffersoni (Rhoades, 1944), O. durelli (Bouchard and Bouchard, 1995) and O. sloanii (Bundy, 1976), ranged from 1.54 to $3.29 \%$.

The match between North American reference sequences and those from the invading populations was substantially lower for $O$. immunis. All analysed European individuals (from both German and French sampling sites) shared the same haplotype, which differed by 2.43 to $3.12 \%$ from the two available sequences of O. immunis from North America (Ontario and Illinois). Similar divergence values were observed between European Orconectes cf. virilis and several other known lineages of the $O$. virilis species complex (altogether, these ranged from 1.14\% to 4.39\%; more details are given in Filipová et al., 2010).

Relatively high variation was observed among sequences from individuals identified as Procambarus cf. acutus or $P$. cf. zonangulus. Sequences of most specimens (9 out of 10) of presumed Procambarus acutus from the Netherlands shared the same haplotype, which was very close to the reference sequence of $P$. acutus from Illinois ( $0.20 \%$ divergence). However, the sequence from one individual (GenBank acc. no. JF437987) differed by $2.33 \%$ from the remaining Dutch individuals, but was very similar $(0.15 \%$ divergence) to the sequence of one individual considered to be $P$. cf. zonangulus from Louisiana (JF437988). Moreover, we also observed substantial variation among all three individuals supposedly representing $P$. cf. zonangulus; with pairwise divergences ranging from $1.38 \%$ to $2.97 \%$.

\section{DISCUSSION}

DNA barcoding has repeatedly been shown to be highly useful for the identification of invasive species (e.g., Armstrong and Ball, 2005; Saunders, 2009; Van de Wiel et al., 2009; Floyd et al., 2010). The method may also be used to distinguish closely related species or cryptic species complexes (e.g., Bickford et al., 2007; Dillman et al., 2010). This also applies to crayfish, where the $\mathrm{COI}$ marker has successfully been used to identify distinct lineages, for example in the 


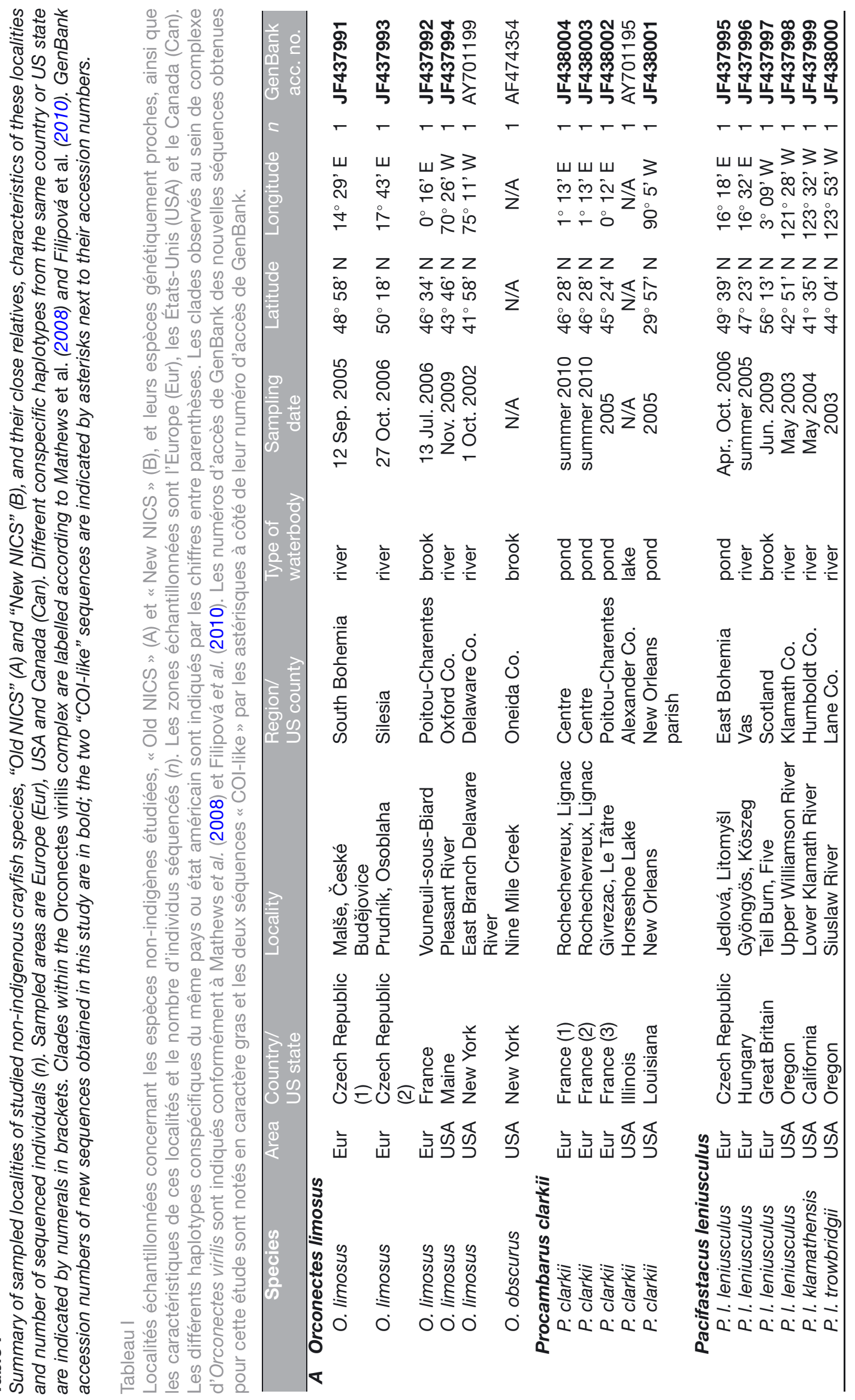


L. Filipová et al.: Knowl. Managt. Aquatic Ecosyst. (2011) 401, 11

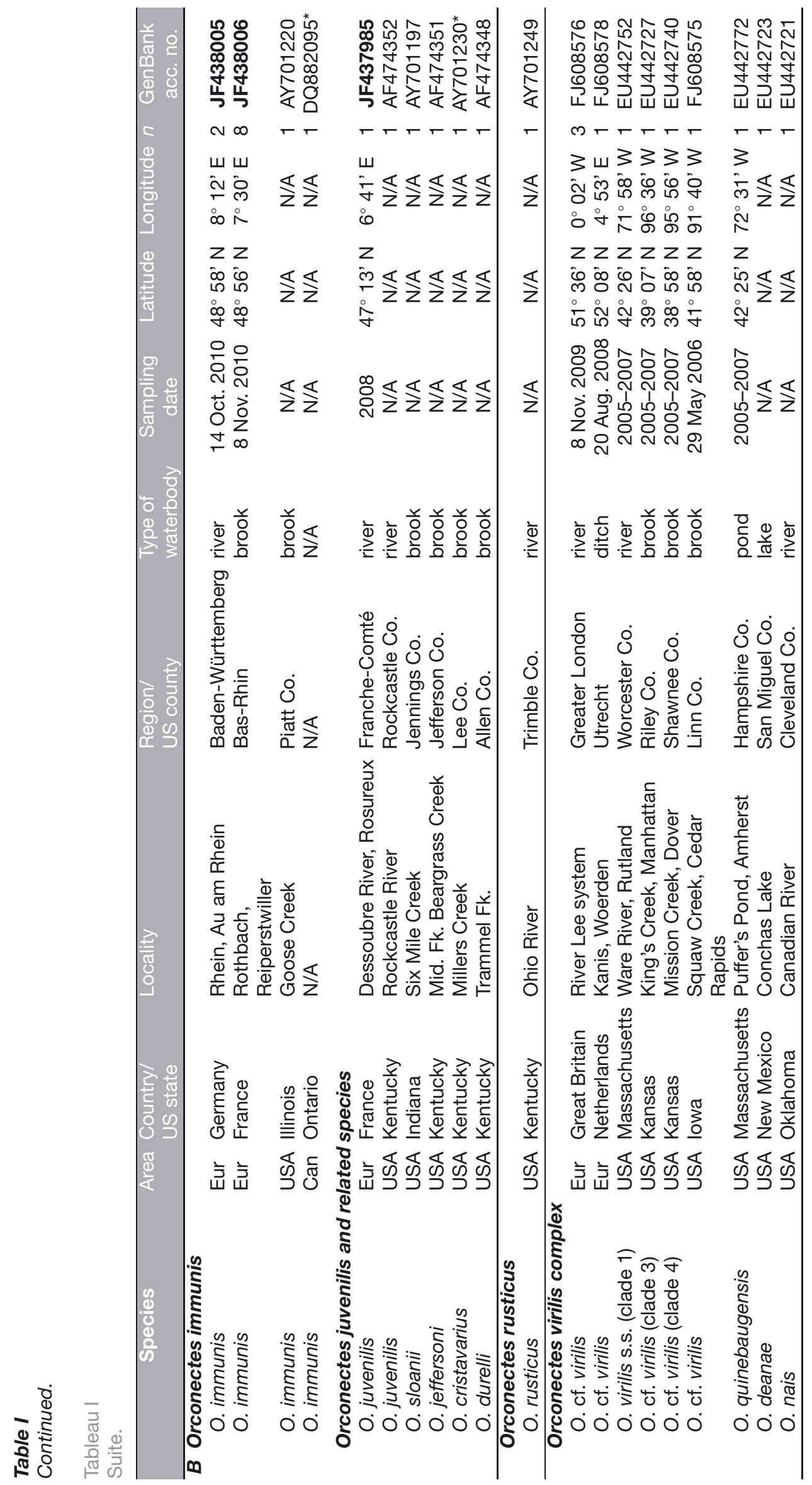




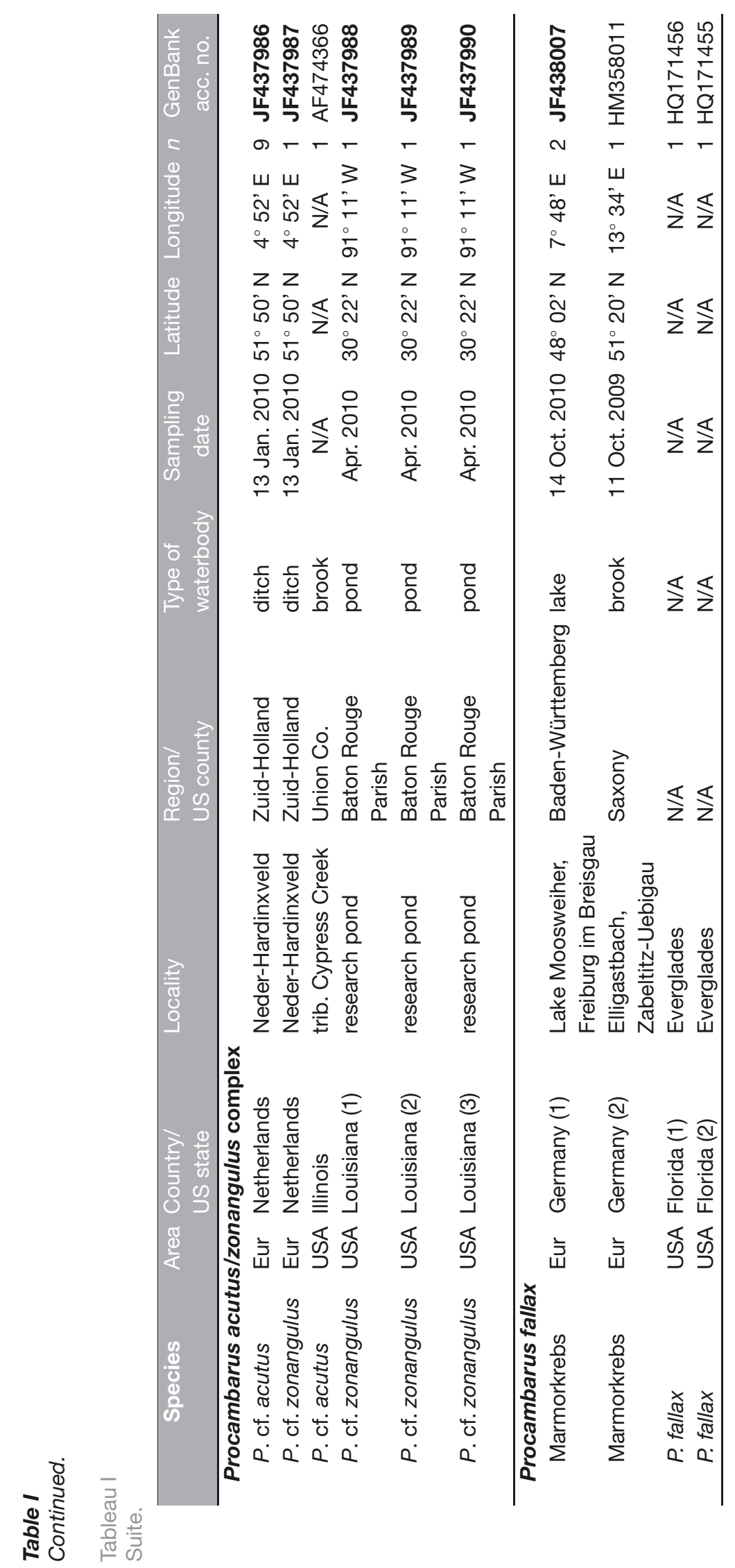




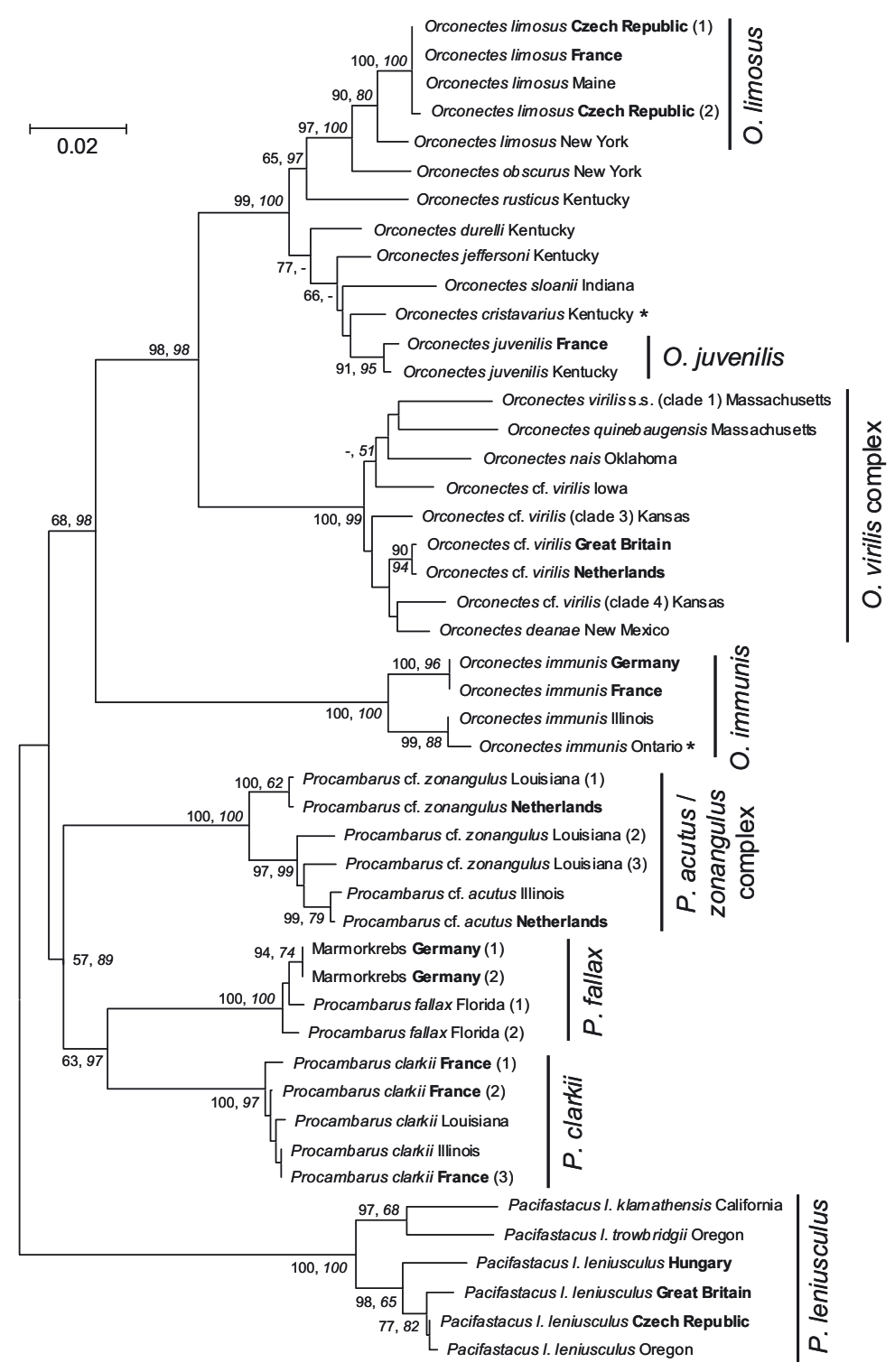

\section{Figure 1}

Neighbour-joining tree showing variation in the cytochome c oxidase subunit I of exotic North American crayfish collected in Europe (countries highlighted in bold), together with reference sequences of these and other closely related species from North America. Numbers at selected nodes indicate the branch support in the neighbour joining (first value) and Bayesian inference (second value, in italics) analyses, respectively; only values above $50 \%$ are shown. Scale indicates $2 \%$ divergence. Different conspecific haplotypes from the same country or US state are indicated by numerals in brackets; the two "COIlike" sequences are marked by asterisks. Clades within the O. virilis complex are labelled according to Mathews et al. (2008) and Filipová et al. (2010).

\section{Figure 1}

Arbre neighbour joining montrant une variation de cytochrome c oxydase sous-unité I (COI) chez les écrevisses d'Amérique du Nord échantillonnées en Europe (pays notés en caractère gras), ainsi que les séquences de référence de ces espèces et des espèces proches provenant d'Amérique du Nord. Les valeurs des nœuds sélectionnés indiquent le support des branches générées par les analyses de neighbour joining (première valeur) et l'inférence bayésienne (seconde valeur, en italique); seules les valeurs au-dessus de 50 \% sont visualisées. L'échelle représente $2 \%$ de divergence. Les différents haplotypes conspécifiques du même pays ou d'un état américain sont indiqués par les chiffres entre parenthèses et les deux séquences “COI-like » par les astérisques à côté de leur numéro d'accès de GenBank. Les clades au sein de complexe d'O. virilis sont marqués conformément à Mathews et al. (2008) et Filipová et al. (2010). 
O. virilis complex (Mathews et al., 2008). An important advantage of the method is the possibility to also identify individuals or development stages lacking characteristics needed for morphological discrimination (Briski et al., 2010; Floyd et al., 2010). North American cambarid crayfish, particularly males, are usually seasonally dimorphic (Hobbs, 1989), and their morphological determination is often based on gonopods of males of reproductively active form I (Hobbs, 1972; Holdich and Reeve, 1988; Hobbs, 1989; Taylor and Knouft, 2006). If individuals of this form are not available, molecular markers may be applied to identify samples.

DNA barcoding may also facilitate the identification of invasive crayfish for researchers (or other stakeholders) that lack experience in morphological analyses in this group. This might be particularly useful in Western and Central Europe where all "New NICS" have been recorded so far (Holdich et al., 2009): the number of native crayfish species in that region is very low, and their identification is relatively easy. On the contrary, the source region of most new invaders, North America, has very high crayfish species richness (Hobbs, 1989). Many American crayfish are genetically as well as morphologically similar (e.g., Taylor and Knouft, 2006; Mathews et al., 2008), so reliable identification requires substantial expertise usually not available in invaded ranges overseas. Of course, molecular-based identification of crayfish invaders is not limited to Europe (for a recent example from Madagascar, see Jones et al., 2009), and may also be useful within North America where crayfish invasions are common as well (Hobbs et al., 1989).

We did not expect any problems with COI-based identification of the "Old NICS", O. limosus, $P$. clarkii and $P$. leniusculus. However, different levels of intraspecific mtDNA variation found in European populations of these species could be expected due to different numbers of introduced individuals of these invaders brought to Europe and the number of introduction events (Souty-Grosset et al., 2006; Barbaresi et al., 2007; Filipová et al., 2009). Analysis of the "New NICS" confirmed the identification of samples from the established marbled crayfish population from Germany (Chucholl and Pfeiffer, 2010) and the O. juvenilis population from France (Chucholl and Daudey, 2008). However, analyses of two other taxa included in our study, O. immunis from Germany and France, and presumed Procambarus acutus from the Netherlands, resulted in ambiguous patterns, similarly as was the case for previously studied European populations considered to be O. virilis (Filipová et al., 2010).

The high divergence between the samples of $O$. immunis from Europe and North America corresponds to divergences found among distinct orconectid species (Figure 1; see also Mathews et al., 2008; Dillman et al., 2010), although comparable or even higher intraspecific variation is observed in other crayfish genera, such as Austropotamobius in Europe (Trontelj et al., 2005) and apparently also Pacifastacus in North America (this study). Variation in the North American range of $O$. immunis should be therefore studied to test whether this taxon is a cryptic species complex, as has recently been shown for O. virilis (Mathews et al., 2008), or whether such levels of divergence are within the range of intraspecific variation.

Similarly, patterns of variation observed among American sequences representing $P$. cf. acutus and $P$. cf. zonangulus confirm that the taxonomy of this species complex needs further analyses. Difficulties in the conclusive identification of white river crayfish found in the Netherlands have already been mentioned by Holdich et al. (2009). Our analysis shows that the local population is not genetically homogeneous and might actually be a mixed population of two species of the white river crayfish complex: although sequences from most Dutch specimens were nearly identical to $P$. cf. acutus sequence from Illinois, one of them was divergent, very similar to $P$. cf. zonangulus from Louisiana. High variation within white river crayfish from the Midwestern USA has been demonstrated by Fetzner et al. (1997), based on allozyme markers. Future analysis of the white river crayfish complex should focus on morphological and genetic variation in their native range (including molecular characterization of both species from the regions of their type localities). However, further research on the invasive population in the Netherlands containing a mixture of haplotypes may also provide important insights; for example, the level of reproductive isolation between divergent lineages may be studied in such localities by nuclear markers. 
These examples also show the importance of comparing newly analysed COI sequence data to appropriate reference sequences. Missing data on relevant taxa may prevent identification, while the presence of a closely related congener but absence of a conspecific in the reference data set may lead to misidentification of the invader (Armstrong and Ball, 2005). Before reaching conclusions on the taxonomic status of seemingly divergent lineages, more data on genetic variation within the concerned taxon should be obtained from the original distribution range. Analyses of nuclear markers may also be desirable to avoid erroneous interpretation of results. Even clearly divergent haplogroups detected by mtDNA barcoding may not necessarily represent biological species (e.g., Dasmahapatra et al., 2009); on the other hand, barcoding may also underestimate the real number of species (e.g., Whitworth et al., 2007). In any case, discoveries of unusual genotypes in invaded ranges may stimulate further research into those particular invasive taxa. We hope this may also be the case for the "New NICS" in Europe, especially as white river crayfish are important for aquaculture in the USA (Huner et al., 1994; Romaire et al., 2005).

In general, DNA barcoding seems to be a useful tool not only for the rapid identification of exotic crayfish but also for a better understanding of their diversity, especially if combined with detailed morphological examinations. Genetic data may be also useful for testing whether newly recorded populations are likely to have been introduced from already established ones, or whether they result from new introductions; such information is important for determining the most important pathways of invasions (Floyd et al., 2010). As most "New NICS" found in Europe are supposed to come from the aquarium trade, knowledge on the genetic variation of specimens available in aquarium cultures could provide useful information on their origin. DNA barcoding can also be applied to well-preserved voucher specimens of uncertain taxonomic status, which might reveal the long-term yet unrecorded presence of invasive species in the area (Humble et al., 2009).

It is likely that more crayfish species will be introduced to Europe in the future, in particular through the aquarium trade or aquaculture (Holdich et al., 2009). As the misidentification of invaders may have negative consequences for risk assessment and future management strategies (Bickford et al., 2007; Floyd et al., 2010), fast and reliable identification of newly recorded invasive crayfish populations is important. The results of our study therefore contribute not only to knowledge on the present diversity of alien crayfish in Europe, but also provide reference data needed for future barcoding-based identification of NICS.

\section{ACKNOWLEDGEMENTS}

We thank R.P. Romaire, M. Collas, A. Ellis, M. Bramard and C. Souty-Grosset for providing crayfish samples, J.W. Fetzner, Jr. for providing COI sequences of Procambarus cf. zonangulus and M. Sonntag for providing $\mathrm{COI}$ sequences of Pacifastacus leniusculus from North America. This study has been funded by ONEMA (Office National de l'Eau et des Milieux Aquatiques) and the Czech Ministry of Education (project no. MSM0021620828). We thank two anonymous reviewers for comments on the manuscript and C. Souty-Grosset for corrections of French.

\section{REFERENCES}

Ahern D., England J. and Ellis A., 2008. The virile crayfish, Orconectes virilis (Hagen, 1870) (Crustacea: Decapoda: Cambaridae), identified in the UK. Aquat. Inv., 3, 102-104.

Armstrong K.F. and Ball S.L., 2005. DNA barcodes for biosecurity: invasive species identification. Phil. Trans. R. Soc. B., 360, 1813-1823.

Barbaresi S., Gherardi F., Mengoni A. and Souty-Grosset C., 2007. Genetics and invasion biology in fresh waters: a pilot study of Procambarus clarkii in Europe. In: Gherardi F. (ed.), Biological invaders in inland waters: Profiles, distribution, and threats, Invading Nature: Springer Series in Invasion Ecology, Springer, Dordrecht, 381-400. 
Bickford D., Lohman D.J., Sodhi N.S., Ng P.K.L., Meier R., Winker K., Ingram K.K. and Das I., 2007. Cryptic species as a window on diversity and conservation. Trends Ecol. Evol., 22, 148-155.

Briski E., Cristescu M.E., Bailey S.A. and Maclsaac H.J., 2010. Use of DNA barcoding to detect invertebrate invasive species from diapausing eggs. Biol. Inv., doi: 10.1007/s10530-010-9892-7.

Buhay J.E., 2009. "COI-like" sequences are becoming problematic in molecular systematic and DNA barcoding studies. J. Crustacean Biol., 29, 96-110.

Chucholl C., 2006. Konkurrenz zwischen zwei Neozoen: Verdrängungs-Mechanismen zwischen Kamberkrebs (Orconectes limosus, Crustacea: Decapoda) und Kalikokrebs (O. immunis). [Competition between two Neozoans: Mechanisms of exclusion between spiny-cheek crayfish (Orconectes limosus, Crustacea: Decapoda) and calico crayfish (O. immunis)]. MSc. thesis, Ulm University, Ulm, $97 \mathrm{p}$.

Chucholl C. and Daudey T., 2008. First record of Orconectes juvenilis (Hagen, 1870) in eastern France: update to the species identity of a recently introduced orconectid crayfish (Crustacea: Astacida). Aquat. Inv. 3, 105-107.

Chucholl C. and Pfeiffer M., 2010. First evidence for an established Marmorkrebs (Decapoda, Astacida, Cambaridae) population in Southwestern Germany, in syntopic occurrence with Orconectes limosus (Rafinesque, 1817). Aquat. Inv. , 5, 405-412.

Chucholl C., Stich H.B. and Maier G., 2008. Aggressive interactions and competition for shelter between a recently introduced and an established invasive crayfish: Orconectes immunis vs. O. limosus. Fund. Appl. Limnol., 172, 27-36.

Dasmahapatra K.K., Elias M., Hill R.I., Hoffman J.I. and Mallet J., 2009. Mitochondrial DNA barcoding detects some species that are real, and some that are not. Mol. Ecol. Res., 10, 264-273.

Daudey T., 2006. Diagnostic des peuplements astacicoles de la vallée du Dessoubre. Master thesis QTEBV, Université de Franche-Comté, Fédération de Pêche du Doubs, 65 p.

Dehus P., Phillipson S., Bohl E., Oidtmann B., Keller M. and Lechleiter S., 1999. German conservation strategies for native crayfish species with regard to alien species. In: Gherardi F. and Holdich D.M. (eds.), Crayfish in Europe as alien species. How to make the best of a bad situation?, A.A. Balkema, Rotterdam, 149-159.

Dillman C.D., Wagner B.K. and Wood R.M., 2010. Phylogenetic estimation of species limits in dwarf crayfishes from the Ozarks: Orconectes macrus and Orconectes nana (Decapoda: Cambaridae). Southeast. Nat., 9, 185-198.

Dussling U. and Hoffmann C., 1998. First discovery of a population of Orconectes immunis in Germany. IAA Newsletter - Crayfish News, 20, 5.

Fetzner J.W. Jr., Sheehan R.J. and Seeb L.W., 1997. Genetic implications of broodstock selection for crayfish aquaculture in the Midwestern United States. Aquaculture, 154, 39-55.

Filipová L., Kozubíková E. and Petrusek A., 2009. Allozyme variation in Czech populations of the invasive spiny-cheek crayfish Orconectes limosus (Cambaridae). Knowl. Managt. Aquatic Ecosyst., 394-395, 10.

Filipová L., Holdich D.M., Lesobre J., Grandjean F. and Petrusek A., 2010. Cryptic diversity within the invasive virile crayfish Orconectes virilis (Hagen, 1870) species complex: new lineages recorded in both native and introduced ranges. Biol. Inv., 12, 983-989.

Floyd R., Lima J., deWaard J., Humble L. and Hanner R., 2010. Common goals: policy implications of DNA barcoding as a protocol for identification of arthropod pests. Biol. Inv., 12, 2947-2954.

Folmer O., Black M., Hoeh W., Lutz R. and Vrijenhoek R., 1994. DNA primers for amplification of mitochondrial cytochrome $c$ oxidase subunit I from diverse metazoan invertebrates. Mol. Mar. Biol. Biotechnol. , 3, 294-299.

Gelmar C., Pätzold F., Grabow K. and Martens A., 2006. The calico crayfish Orconectes immunis at the northern Upper Rhine: a newly introduced American crayfish is spreading rapidly in Central Europe (Crustacea: Cambaridae). Lauterbornia, 56, 15-25 (in German with English abstract).

Gherardi F. and Holdich D.M. (eds.), 1999. Crayfish in Europe as alien species. How to make the best of a bad situation?, A.A. Balkema, Rotterdam, Brookfield, 299 p.

Grandjean F. and Souty-Grosset C., 1997. Preliminary results on the genetic variability of mitochondrial DNA in the signal crayfish, Pacifastacus leniusculus Dana. C. R. Acad. Sci. III, 320, 551-556.

Hebert P.D.N., Ratnasingham S. and deWaard J.R., 2003. Barcoding animal life: cytochrome $c$ oxidase subunit 1 divergences among closely related species. Proc. R. Soc. Lond. B (Suppl.), 270, S96-S99. 
Hobbs H.H. Jr., 1972. Biota of Freshwater Ecosystems: Identification Manual No. 9, Crayfishes (Astacidea) of North and Middle America, For the Environmental Protection Agency, Project \# 18050 ELD. Available at: http://iz.carnegiemnh.org/crayfish/Keys/index2.htm (accessed on 29th December 2010).

Hobbs H.H. Jr., 1989. An illustrated checklist of the American crayfishes (Decapoda: Astacidae, Cambaridae, and Parastacidae). Smiths. Contrib. Zool., 480, 236 p.

Hobbs H.H. III, Jass J.P. and Huner J.V., 1989. A review of global crayfish introductions with particular emphasis on two North American species (Decapoda, Cambaridae). Crustaceana, 56, 299-316.

Holdich D.M., 2003. Crayfish in Europe - an overview of taxonomy, legislation, distribution, and crayfish plague outbreaks. In: Holdich D.M. and Sibley P.J. (eds.), Management and Conservation of Crayfish, Proceedings of a conference held on 7th November 2002 at the Nottingham Forest Football Club, Nottingham, UK, Environment Agency, Bristol, 15-34.

Holdich D.M. and Reeve I.D., 1988. Functional morphology and anatomy. In: Holdich D.M. and Lowery R.S. (eds.), Freshwater crayfish: biology, management and exploitation, London, Chapman and Hall, 11-51.

Holdich D.M., Reynolds J.D., Souty-Grosset C. and Sibley P.J., 2009. A review of the ever increasing threat to European crayfish from non-indigenous crayfish species. Knowl. Managt. Aquatic Ecosyst., 394-395, 11.

Hulák M., Kašpar V., Kozák P., Filipová L. and Petrusek A., 2010. Cross-species amplification of microsatellite markers in the invasive spiny-cheek crayfish (Orconectes limosus): assessment and application. J. Appl. Genet., 51, 73-78.

Humble L.M., DeWaard J.R. and Quinn M., 2009. Delayed recognition of the European poplar shoot borer, Gypsonoma aceriana (Duponchel) (Lepidoptera: Tortricidae), in Canada. J. Entomol. Soc. Brit. Columbia, 106, 61-70.

Huner J.V., Moody M. and Thune R., 1994. Cultivation of freshwater crayfishes in North America. In: Huner J.V. (ed.), Freshwater crayfish aquaculture in North America, Europe, and Australia, Families Astacidae, Cambaridae, Parastacidae, Food Product Press, New York, 5-156.

Jones J.P., Rasamy J.R., Harvey A., Toon A., Oidtmann B., Randrianarison M.H., Raminosoa N. and Ravoahangimalala O.R., 2009. The perfect invader: a parthenogenetic crayfish poses a new threat to Madagascar's freshwater biodiversity. Biol. Inv., 11, 1475-1482.

Kossakowski J., 1966. Raki [Crayfish]. Panstwowe wydawnictwo rolnicke i lesne, Warszawa, 292 p. (in Polish).

Martin P., Dorn N.J., Kawai T., van der Heiden C. and Scholtz G., 2010a. The enigmatic Marmorkrebs (marbled crayfish) is the parthenogenetic form of Procambarus fallax (Hagen, 1870). Contrib. Zool., 79, 107-118.

Martin P., Shen H., Füllner G. and Scholtz G., 2010b. The first record of the parthenogenetic Marmorkrebs (Decapoda, Astacida, Cambaridae) in the wild in Saxony (Germany) raises the question of its actual threat to European freshwater ecosystems. Aquat. Inv., 5, 397-403.

Marzano F.N., Scalici M., Chiesa S., Gherardi F., Piccinini A. and Gibertini G., 2009. The first record of the marbled crayfish adds further threats to fresh waters in Italy. Aquat. Inv. , 4, 401-404.

Mathews L.M., Adams L., Anderson E., Basile M., Gottardi E. and Buckholt M.A., 2008. Genetic and morphological evidence for substantial hidden biodiversity in a freshwater crayfish species complex. Mol. Phylogenet. Evol., 48, 126-135.

Nylander J.A.A., 2004. MrModeltest 2.3. Program distributed by the author, Evolutionary Biology Centre, Uppsala University.

Pöckl M., Holdich D.M. and Pennerstorfer J., 2006. Identifying native and alien crayfish species in Europe, European Project CRAYNET, $47 \mathrm{p}$.

Romaire R.P., McClain W.R., Shirley M.G. and Lutz C.G., 2005. Crawfish aquaculture - marketing, Southern Regional Aquaculture Center, SRAC Publication, 2402, 1-8.

Ronquist F. and Huelsenbeck J.P., 2003. MrBayes 3: Bayesian phylogenetic inference under mixed models. Bioinformatics, 19, 1572-1574.

Saunders G.W., 2009. Routine DNA barcoding of Canadian Gracilariales (Rhodophyta) reveals the invasive species Gracilaria vermiculophylla in British Columbia. Mol. Ecol. Res., 9, 140-150.

Scalici M., Chiesa S., Gherardi F., Ruffini M., Gibertini G. and Marzano F.N., 2009. The new threat to Italian inland waters from the alien crayfish "gang": the Australian Cherax destructor Clark, 1936. Hydrobiologia, 632, 341-345. 
Scholtz G., Braband A., Tolley L., Reimann A., Mittmann B., Lukhaup C., Steuerwald F. and Vogt G., 2003. Parthenogenesis in an outsider crayfish. Nature, $421,806$.

Soes D.M. and van Eekelen R., 2006. Rivierkreeften, een oprukkend probleem? [Are exotic crayfish becoming a problem?]. De Levende Natuur, 107, 56-59.

Souty-Grosset C., Holdich D.M., Noël P.Y., Reynolds J.D. and Haffner P., 2006. Atlas of crayfish in Europe. In: Patrimoines naturels, 64, Muséum national d'Histoire naturelle, Paris.

Tamura K., Dudley J., Nei M. and Kumar S., 2007. MEGA4: molecular evolutionary genetics analysis (MEGA) software version 4.0. Mol. Biol. Evol., 24, 1596-1599.

Taylor C.A., 2000. Systematic studies of the Orconectes juvenilis complex (Decapoda: Cambaridae), with descriptions of two new species. J. Crustacean Biol., 20, 132-152.

Taylor C.A. and Hardman M., 2002. Phylogenetics of the crayfish subgenus Crockerinus, genus Orconectes (Decapoda: Cambaridae), based on cytochrome oxidase I. J. Crustacean Biol., 22, 874-881.

Taylor C.A. and Knouft J.H., 2006. Historical influences on genital morphology among sympatric species: gonopod evolution and reproductive isolation in the crayfish genus Orconectes (Cambaridae). Biol. J. Linn. Soc., 89, 1-12.

Trontelj P., Machino Y. and Sket B., 2005. Phylogenetic and phylogeographic relationships in the crayfish genus Austropotamobius inferred from mitochondrial COI gene sequences. Mol. Phylogenet. Evol., 34, 212-226.

Van de Wiel C.C.M., Van der Schoot J., Van Valkenburg J.L.C.H., Duistermaat H. and Smulders M.J.M., 2009. DNA barcoding discriminates the noxious invasive plant species, floating pennywort (Hydrocotyle ranunculoides L.f.), from non-invasive relatives. Mol. Ecol. Res., 9, 1086-1091.

Westman K., 2002. Alien crayfish in Europe: negative and positive impacts and interactions with native crayfish. In: Leppäkoski E., Gollasch S. and Olenin S. (eds.), Invasive aquatic species of Europe, Distribution, impacts and management, Kluwer Academic Publishers, the Netherlands, 76-95.

Whitworth T.L., Dawson R.D., Magalon H. and Baudry E., 2007. DNA barcoding cannot reliably identify species of the blowfly genus Protocalliphora (Diptera: Calliphoridae). Proc. R. Soc. B, 274, $1731-1739$. 